\title{
Correlation of English and German Middle Pleistocene fluvial sequences based on mammalian biostratigraphy
}

\section{D.C. Schreve ${ }^{1^{*}} \&$ D.R. Bridgland ${ }^{2}$}

' Department of Geography, Royal Holloway, University of London, Egham, Surrey, TW20 0EX, UK; e-mail: Danielle.Schreve@rhul.ac.uk.

* Corresponding author.

2 Department of Geography, University of Durham, South Road, Durham, DH1 3LE, UK; e-mail: D.R.Bridgland@durham.ac.uk

Manuscript received: March 2001; accepted: February 2002

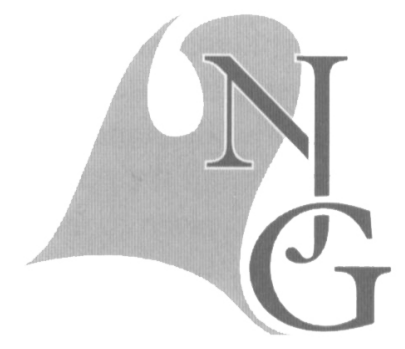

\begin{abstract}
In this paper interglacial mammalian assemblages from key Middle Pleistocene fluvial sites in Germany are compared to Mammal Assemblage-Zones (MAZs) recently established in the post-Anglian/Elsterian sequence of the Lower Thames, UK. It is believed that four separate interglacials are represented by the Lower Thames MAZs, correlated with oxygen isotope stages (OIS) 11, 9, 7 and substage 5e (although the last of these is Late Pleistocene). Nowhere in Germany can a full sequence of these interglacials be identified from mammalian evidence in a single terrace staircase, as is the case in the Lower Thames, although further research on the Wipper terraces at Bilzingsleben may identify such a sequence. It is also possible that the sequence of overlapping fluvial channels in the lignite mine at Schöningen will eventually produce a comparable mammalian story. Excellent correspondence has been recognized between the mammalian assemblages at Steinheim an der Murr and Bilzingsleben II and the Swanscombe MAZ from the Thames. These three sites are attributed to the Hoxnian/Holsteinian interglacial and are thought to correlate with OIS 11. Close comparison can also be made between the mammalian sequence from the celebrated travertine locality at Weimar-Ehringsdorf and two separate MAZs from Aveley, in the Thames, attributed to separate substages of OIS 7. An equivalent to the Purfleet MAZ of the Thames, which is believed to correlate with OIS 9, has yet to be identified in Germany.
\end{abstract}

Keywords: biostratigraphy, mammals, Middle Pleistocene, river terraces

\section{Introduction}

This paper provides part of the results from a research project, conducted by the authors between 1997-2000, entitled 'Middle Pleistocene mammalian biostratigraphy of NW European rivers' (funded by the Leverhulme Trust - see acknowledgements). Prior to the project, the first author had established a scheme for the differentiation of interglacials in the British late Middle Pleistocene, based upon the evidence from mammalian biostratigraphy (Schreve, 1997). The scheme identified a series of distinctive temperate-climate Mammal Assemblage Zones (MAZ) that are believed to correspond with three separate interglacials between the Anglian glaciation and the Last (Ipswichian) Interglacial (Schreve, 2001a). These findings were in complete support of the model for the lithostratigraphy and geochronology of the Lower Thames terraces, proposed previously by the second author (Bridgland, 1994, 1995). The extension of the project into continental Europe was based on the selection of key fluvial sites with rich assemblages of fossil mammals, the examination of those collections and, where possible, liaison with continental workers who have researched them. In this part of the project, it was found that evidence from sites in Germany was particularly comparable with the British mammalian biostratigraphical data. 
The present paper will outline the Thames mammalian biostratigraphical scheme, regarded as a potential template for correlation both within Britain and more widely in NW Europe, and then examine the evidence from selected sites in Germany.

\section{The Lower Thames terrace sequence}

The terrace stratigraphical model based on the Lower Thames sequence has been described several times previously (Bridgland, 1994, 1995, 2000), information that is summarized in Table 1 and is illustrated in Fig. 1.

It is believed that formation of the Thames terraces was driven by climatic fluctuation during the Quaternary (Bridgland, 1994, 1995, 2000; Bridgland \& Maddy, 1995), although enabled by progressive uplift throughout the Pleistocene (Maddy, 1997; Maddy \& Bridgland, 2000). The climatic fluctuation that has driven the timing of fluvial incision and aggradation, thus leading to terrace formation, has also been important in controlling the migration of different groups of mammals into and out of the NW European landmass. In Britain, relatively brief periods of past insularity, also climatically controlled, must also be taken into account, as they will have temporarily acted as a barrier to faunal migration. Britain's peri- odic isolation may be an important factor in permitting the separation of mammalian assemblages of different age, since patterns of species presence and absence between interglacials should be all the more significant, depending on whether individual taxa were able to immigrate before the terrestrial connection was severed. There is no evidence for the evolution of endemic mammalian species during this time period in Britain, although it appears that endemic technological traits can be seen in the archaeological record corresponding with periods of isolation from mainland Europe (White, 1998; White \& Schreve, 2000). A key aim of the Leverhulme-funded project has therefore been to determine whether signs of insularity-related differences between contemporaneous faunas on either side of the English Channel can be detected.

\section{Mammalian assemblages from the Lower Thames terrace sequence}

Sites within the framework of the Lower Thames terrace sequence were used by Schreve $(1997,2001$ a) to erect the testable hypothesis that interglacial sediments within each of four separate terraces (Table 1, Fig. 1) contained distinctive suites of mammalian fossils. Biostratigraphical analysis of these different

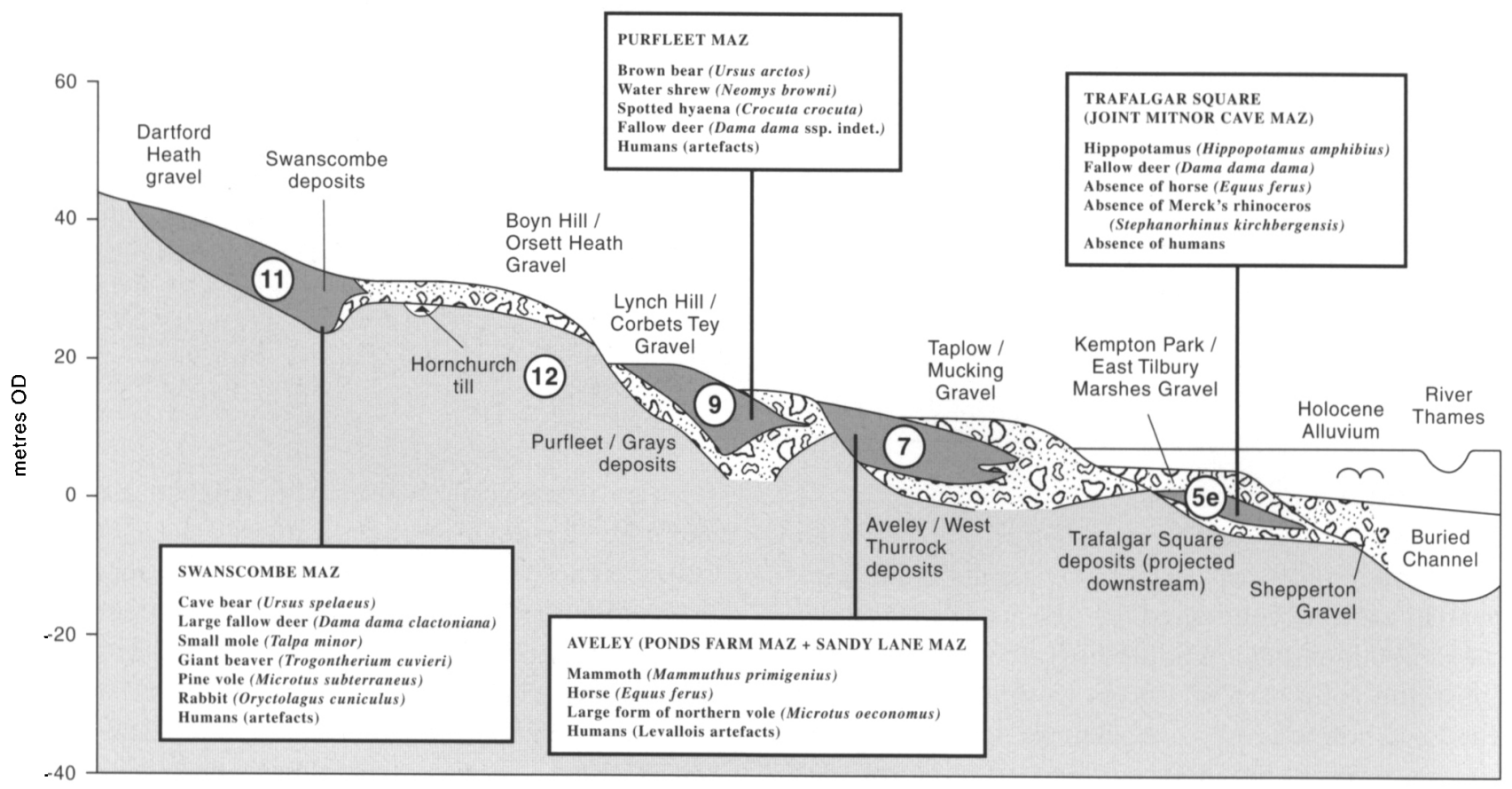

(11) Numbers indicate the oxygen isotope stages to which these deposits have been attributed

Fig. 1. Idealized transverse section through the Lower Thames terrace sequence, showing the stratigraphical positions of interbedded interglacial sediments. The most significant characteristics of the mammalian assemblages and their attribution to MAZs are indicated (after Schreve, 2001a; Currant \& Jacobi, 2001). Correlations with the oceanic oxygen isotope sequence are suggested. Modified from Schreve (2001a). 
Table 1.The Quaternary sequence in the lower reaches of the Thames.

\begin{tabular}{|c|c|c|c|c|}
\hline Terrace Formation & Members: Lower Thames & Climate & Age & $\delta{ }^{18} \mathrm{O}$ Stage \\
\hline Tilbury & Tilbury Alluvial Deposits & warm & Holocene (alluvium) & 1 \\
\hline Shepperton & Shepperton Gravel & cold & late Devensian & late 2 \\
\hline \multirow[t]{3}{*}{ East Tilbury Marshes } & East Tilbury Marshes Upper Gravel & cold & Devensian & $5 d-2$ \\
\hline & Trafalgar Square \& Peckham Deposits & warm & Ipswichian & $5 \mathrm{e}$ \\
\hline & East Tilbury Marshes Lower Gravel & cold & late Saalian & late 6 \\
\hline \multirow[t]{4}{*}{ Mucking } & Mucking Upper Gravel & cold & late Saalian & 6 \\
\hline & Aveley Silts and Sands & warm & intra-Saalian 'Stanton & 7 \\
\hline & & & Harcourt Interglacial & \\
\hline & Mucking Lower Gravel & cold & $\begin{array}{l}\text { Bowen et al. (1989) } \\
\text { intra-Saalian }\end{array}$ & late 8 \\
\hline \multirow[t]{3}{*}{ Corbets Tey } & $\begin{array}{l}\text { Corbets Tey Upper Gravel } \\
\text { (Botany Gravel }{ }^{1} \text { ) }\end{array}$ & cold & intra-Saalian & 8 \\
\hline & Purfleet interglacial deposits & warm & intra-Saalian & 9 \\
\hline & $\begin{array}{l}\text { Corbets Tey Lower Gravel } \\
\text { (Little Thurrock Gravel }{ }^{1} \text { ) }\end{array}$ & cold & intra-Saalian & late 10 \\
\hline \multirow[t]{3}{*}{ Orsett Heath } & Orsett Heath Upper Gravel & cold & intra-Saalian & 10 \\
\hline & Swanscombe interglacial deposits & warm & Hoxnian & 11 \\
\hline & Orsett Heath Lower Gravel & cold & late Anglian & late 12 \\
\hline
\end{tabular}

' From Schreve et al. (2002)

assemblages suggested that four discrete Mammal Assemblage-Zones (MAZs) may be recognized within the Lower Thames (Fig. 1), which are thought to represent OIS 11, 9 and a complex, dual-peaked OIS 7, all of which clearly pre-date the Last (Ipswichian) Interglacial (OI substage 5e). The mammalian biostratigraphical scheme thus corroborated and extended the scheme of Bridgland $(1994,1995)$, established on the basis of lithostratigraphical evidence. The Anglian/Elsterian glacial is here correlated with OIS 12 , as is widely favoured in Britain (Bowen et al., 1986, 1989; Bowen, 1999; Rowe et al., 1999; Scourse et al., 1999) and further afield (Sarnthein et al., 1986; Shackleton, 1987; Ehlers et al., 1991), although some Dutch and German workers have correlated the Elsterian, or at least the latest part of it, with OIS 10 (De Jong, 1988; Klostermann, 1995; Urban, 1995; Roebroeks \& Van Kolfschoten, 1996; Zagwijn, 1996).

As indicated above, it has also been possible to identify subdivisions within some of the earliest three temperate stages. There is good evidence for believing that these subdivisions represent smaller-scale climatic and environmental fluctuations within the interglacials, caused by oscillations of palaeoclimate at oxygen isotope substage level as well as changes in relative sea-level driven by climate and/or glacioisostasy (White \& Schreve, 2000; Schreve, 2001b). The fourth interglacial, the Eemian/Ipswichian, is already identified at the oxygen isotope substage level, with later, cooler temperate episodes within OIS 5 classified as interstadials.

\section{Mammalian assemblages from the first post-Anglian interglacial.}

The first of the late Middle Pleistocene interglacials is represented in the Lower Thames only in the Dartford - Swanscombe area of Kent (Fig. 2), with the majority of the mammalian evidence coming from the adjacent sites of Barnfield Pit at Swanscombe and Dierden's Pit, Ingress Vale (Sutcliffe, 1964).

This particular faunal grouping has been assigned to the Swanscombe MAZ by Schreve (2001a), with taxa of biostratigraphical significance including the extinct small mole (Talpa minor), the extinct giant beaver (Trogontherium cuvieri), the rabbit (Oryctolagus cuniculus), the European pine vole (Microtus (Terricola) subterraneus) (= Pitymys arvaloides), the cave bear (Ursus spelaeus) and the large sub-species of fallow deer (Dama dama clactoniana). U. spelaeus and D. d. clactoniana are unique to the first post-Anglian interglacial in Britain, whereas the remainder are known also from the interglacials of the 'Cromerian Complex'. Most critically, however, none of these 'indicator species' has been recovered from British Pleistocene deposits any later than those of the first postAnglian interglacial, although $O$. cuniculus and $M$. (T.) subterraneus are still extant. The Swanscombe 


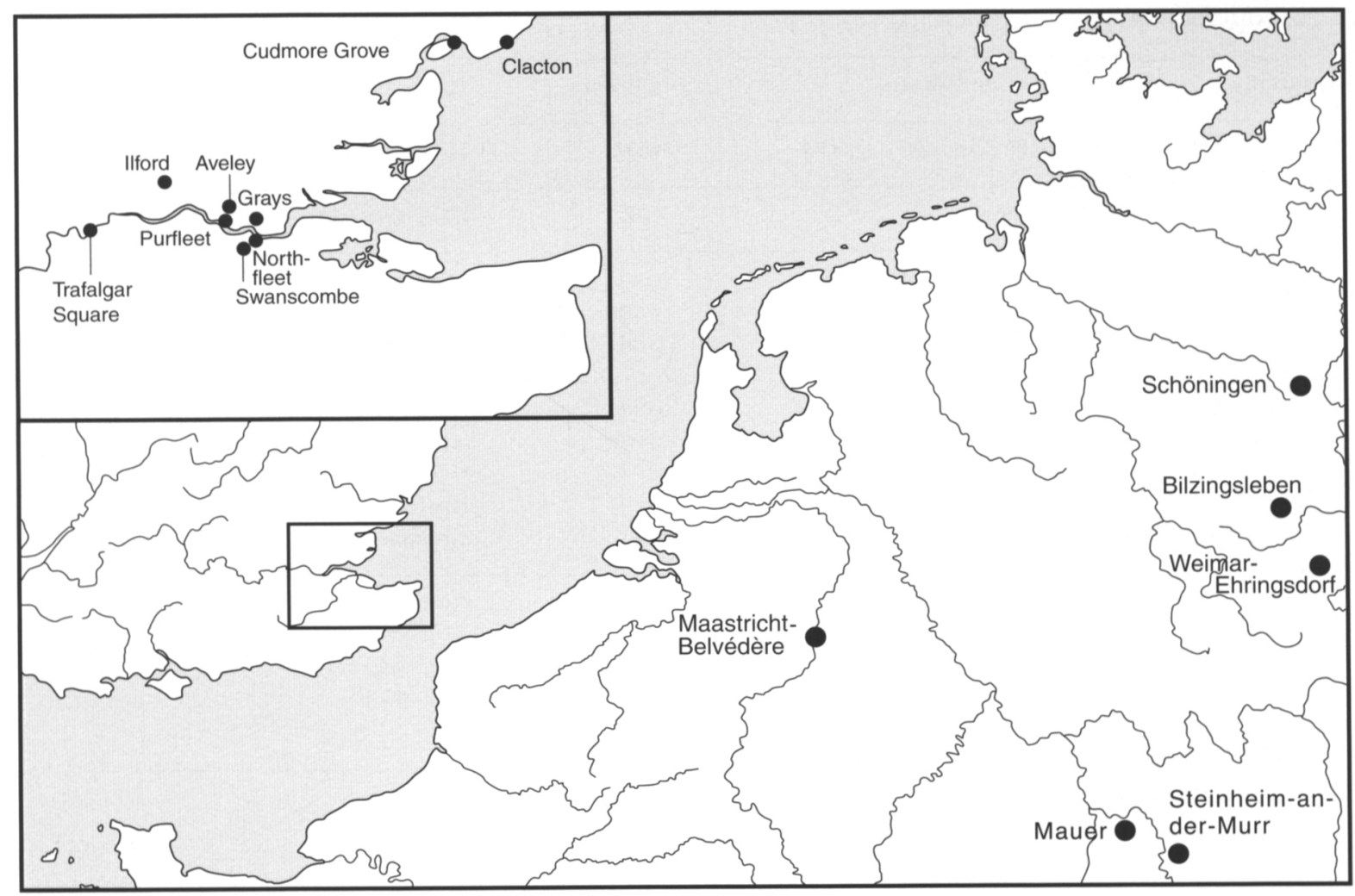

Fig. 2. Location map of the sites discussed in the paper.

MAZ also marks the first appearance in the British fossil record of Merck's rhinoceros (Stephanorhinus kirchbergensis), narrow-nosed rhinoceros (Stephanorhinus hemitoechus), the giant deer Megaloceros giganteus, aurochs (Bos primigenius) and the extinct stenonid horse Equus hydruntinus. In addition the sequence at Barnfield Pit is thought to represent two separate temperate phases, with evidence for cold climate conditions during the interval between them, in the form of solifluction deposits. These are considered to represent substages of the OIS 11 interglacial (Schreve, 1997, 2001b; see below). All the mammalian evidence, however, is from the first of these, as the uppermost part of the Swanscombe sequence is decalcified. The downstream correlative site at Clacton-on-Sea, type locality of the Clactonian Palaeolithic Industry (Warren, 1955; Bridgland et al., 1999), provides useful comparative data. The mammalian assemblage from Clacton is very similar to that from Swanscombe, since all the species recorded at the former are also known from Barnfield Pit. Two biostratigraphically significant elements, namely $T$. cuvieri and D. d. clactoniana, are present at Clacton, permitting the attribution of this assemblage to the Swanscombe MAZ. Comparison of mammalian assemblages from Swanscombe and Clacton with those from Hoxne (the stratotype of the Hoxnian Interglacial) suggests that these faunas should all be grouped within the Swanscombe MAZ and that the
Hoxnian should consequently be correlated with OIS 11 (Schreve, 2000, 2001a).

Mammalian assemblages from the second post-Anglian interglacial.

The second interglacial in the sequence, thought to equate with OIS 9 of the oceanic record, is represented at several sites within the Lower Thames. These sites all coincide with sediments of the Lynch Hill/Corbets Tey Formation (Fig. 1) and are located at Stoke Newington/Hackney (Harding \& Gibbard, 1984; Bridgland, 1994), Ilford (high-level sites; see Bridgland, 1994), Upminster (Ward, 1984), Belhus Park (Gibbard, 1994; Bridgland, 1994), Purfleet (Schreve et al., 2002) and Grays Thurrock (Morris, 1836) (Fig. 2). New work on the sites at Hackney and Purfleet has been undertaken as part of the Leverhulme-funded project. The research at Hackney is still in progress but that at Purfleet has provided significant new information, building on preliminary work there reported by Schreve (1997). The interglacial sediments at Purfleet and its correlatives have yielded a biostratigraphically diagnostic suite of mammals (the Purfleet MAZ) that differs from the older Swanscombe MAZ in a number of important ways (Schreve, 2001a; Schreve et al., 2002). Despite extensive sieving for microvertebrate remains, the recovery of large and diverse micro- and macrofaunal assem- 
blages and the physical proximity and similar environmental conditions of the Purfleet MAZ sites to the Swanscombe MAZ localities in the Thames valley, not a single example of the aforementioned Swanscombe MAZ 'indicator species' has been recovered from these deposits. Thus, in the case of the small mammals, T. minor, T. cuvieri, O. cuniculus and $M$. (T.) subterraneus are all absent from the Purfleet $M A Z$, whereas amongst the larger mammals, the brown bear Ursus arctos has supplanted the cave bear $U$. spelaeus, the fallow deer is now represented by a smaller animal than D.d. clactoniana, and the spotted hyaena (Crocuta crocuta) makes its first appearance in Britain since the 'Cromerian Complex'. The Purfleet MAZ may be distinguished from younger interglacial assemblages by the presence of macaque monkey (Macaca sylvanus), which is unknown from all later British Pleistocene deposits, and by the evolutionary stage attained in the molars of water vole (Arvicola terrestris cantiana) (see Heinrich, 1982, 1987). A combination of horse (Equus ferus), humans (Homo sp.) (attested to by artefacts and butchery marks on bones) and Merck's rhinoceros clearly differentiates the fauna of the Purfleet MAZ from those of the Ipswichian Interglacial (Currant, 1989; Sutcliffe, 1995a).

Mammalian assemblages from the third post-Anglian interglacial.

The penultimate temperate episode, the third late Middle Pleistocene interglacial, has been recognized within the Lower Thames for some years (Sutcliffe, 1964) and has been widely correlated with OIS 7 (Shotton, 1983; Bridgland, 1994). It is represented in the Mucking Formation at Ilford (low-level Uphall site), Aveley (Anon., 1966; Sutcliffe, 1995b), West Thurrock (Bridgland \& Harding, 1994) and, in the tributary Ebbsfleet valley, at Northfleet (Bridgland, 1994). The construction in SW Essex of a new A13 dual carriageway road has recently provided an unprecedented opportunity to examine, record and sample the fossiliferous Aveley Silts and Sands (Schreve, 1997). The sediments at Aveley record a complex climatic signal within a single interglacial, with two (and possibly three) temperate-climatic episodes identified, separated by breaks in deposition. As at Swanscombe, these are also thought to reflect climatic oscillation at the isotope substage level (Schreve, 2001b). The mammalian fauna from Aveley may be subdivided into two discrete groups, termed the Ponds Farm MAZ and the Sandy Lane MAZ, and considered to reflect the earlier part of the interglacial and the later part of the interglacial respectively (Schreve, 2001a, 2001b; Table 2).
The Ponds Farm MAZ is represented in the oldest temperate-climate sediments at Aveley, namely the Aveley sands and lower silts (Fig. 5). These have yielded vertebrate assemblages that are predominantly characteristic of woodland and which include thermophilous taxa such as common mole (Talpa cf. europaea), European pond terrapin (Emys orbicularis), a white-toothed shrew (Crocidura sp.) and straighttusked elephant (Palaeoloxodon antiquus). Horse is present but woolly mammoth (Mammuthus primigenius) is apparently absent (Schreve, 2001a). The sands and lower silts are separated by an unconformity, indicating that erosion took place between the two phases of deposition, although the cause and duration of this hiatus are as yet unknown. A second break in deposition is evident near the top of the lower silts, indicated by the development of a soil (R. Kemp, pers. comm., 1996). This is considered to represent a land surface, possibly exposed during a period of cooler conditions, during which time new species were able to colonize Britain (Schreve, 1997, 2001b). A return to temperate climatic conditions is indicated by a detritus mud and by the Aveley upper silts, which have yielded rich vertebrate assemblages assigned to the Sandy Lane MAZ (Schreve, 2001a). In contrast to the Ponds Farm MAZ of the earlier part of the interglacial, the Sandy Lane MAZ is defined by a predominance of open grassland taxa, in particular woolly mammoth and horse. $M$. primigenius is represented frequently (but not exclusively) by the biostratigraphically diagnostic 'Ilford type' mammoth, a morphologically less-derived form characterized by a combination of small size and low plate count in the molars. An important absentee from the Sandy Lane MAZ is the fallow deer (Dama dama dama). This, in addition to the presence of horse and mammoth and evidence of humans (in the form of fresh flint artefacts), differentiates the Sandy Lane MAZ from assemblages of Last Interglacial age (contra Stuart, 1976).

\section{Mammalian assemblages of the Last Interglacial.}

The most recent of the four interglacials in the Lower Thames sequence is identified as the Ipswichian or Last Interglacial (OIS 5e) and, being of Late Pleistocene age, strictly falls outside of the scope of this paper. However, it is important that the distinctive mammalian assemblage from this episode is recognized and distinguished from three earlier, late Middle Pleistocene interglacials, particularly since the OIS 9 and OIS 7 deposits have both been mistakenly attributed to the Ipswichian in the past (cf West, 1969; Hollin, 1977; Gibbard, 1994, 1995). The mam- 
malian assemblage of the Last Interglacial (named the Joint Mitnor Cave MAZ by Currant \& Jacobi, 2001) is characterized by taxa such as hippopotamus (Hippopotamus amphibius, the only record of the extant species from the British Pleistocene), fallow deer, straight-tusked elephant and narrow-nosed rhinoceros. Assemblages of this age, such as the one from Trafalgar Square in central London (Franks et al., 1958), are further characterized by the absence of horse, humans and Merck's rhinoceros, all of which are known from the three earlier post-Anglian interglacials. It should be noted that the Last Interglacial is already defined at the oxygen isotope substage level. Other assemblages, lacking in hippopotamus and with the addition of northern vole (Microtus oecono$m u s$ ), have been assigned to later parts of OIS 5 , for example at Bacon Hole, Gower (Currant \& Jacobi, 2001), thereby supporting the view that substages within warm oxygen isotope stages can be distinguished on the basis of mammalian biostratigraphy (see Schreve, 2001a, 2001b).

\section{Correlation with mammalian sites in other British river systems}

Bridgland \& Schreve (2001) have described the use of the mammalian biostratigraphical scheme from the Lower Thames as a template for dating and correlating sites in other English river systems, specifically the Upper Thames, the Severn-Avon, the Solent and the Fenland rivers. None of these has a mammalian record comparable, in terms of completeness, with that from the Lower Thames. The authors also demonstrated how evidence from other depositional environments can be integrated into the story, making use of mammalian assemblages from English southcoast raised beaches to reinforce the rather sparse faunal evidence from the Solent river terraces. The mammalian scheme can also be of considerable value in assessing the age of mammalian assemblages from depositional environments that cannot be placed within frameworks such as those provided by river terraces and raised beach staircases. Thus, Schreve (2000, 2001a) has used mammalian evidence to demonstrate that the type Hoxnian lacustrine sediments date from the first post-Anglian/Elsterian interglacial, OIS 11 , by correlating them with the mammal-bearing sites at Swanscombe and Clacton (see above). Similarly, the mammalian biostratigraphical scheme may be applied in cases where the palynological evidence has been unable to discriminate between two successive interglacials, for example in sediments of the proto-Colne at Cudmore Grove, Essex. Here, organic deposits yielding rich vertebrate assemblages have produced pollen spectra that invite correlation with either the Hoxnian Interglacial or with a younger, as yet unnamed, Middle Pleistocene interglacial (Roe, 1999). Mammalian biostratigraphical evidence, namely the recognition at Cudmore Grove of the Purfleet MAZ, clearly advocates the placing of the temperate-climate deposits within the younger of these two interglacial episodes, that correlated with OIS 9 (Schreve, 2001a).

\section{Mammalian evidence from fluvial sequences in Germany}

The study undertaken in Germany was by no means exhaustive. No sequence of mammal-bearing interglacial deposits comparable in completeness to that of the Thames has been identified. Although sequences from the River Wipper in Thüringen, and from a subsiding basin at Schöningen, near Magdeburg, appear to have complete records of late Middle Pleistocene glacial-interglacial fluctuation, not all of the interglacial levels have thus far produced mammalian fossils. The preservation of mammal bones and teeth is likely to be highly localized and controlled by groundwater conditions, as in Britain. The data from Germany will be described under individual river systems.

\section{River Neckar: Mauer, near Heidelberg}

The Grafenrain sand pit, near the village of Mauer, preserves a sequence of Middle Pleistocene interglacial fluviatile deposits that were laid down by the River Neckar in the cut-off Hollmuth meander loop. The site is celebrated for the discovery there, in 1907, of the type specimen of Homo heidelbergensis (Figs $2 \& 3$ ).

The sands are overlain by a loess sequence, within which at least three full climatic cycles have been recognized (Bosinski, 1996). A small mammal assemblage of Upper Pleistocene age is recorded from the loess), although only the mammals from the fossiliferous lower sands were examined during the present study. This latter fauna is characteristic of the early Middle Pleistocene and contains extinct taxa such as the vole Pliomys episcopalis, the small wolf Canis lupus mosbachensis, the cave bear Ursus deningeri, the hyaena Hyaena perrieri, a sabre-toothed cat Homotherium sp., the rhinoceros Stephanorhinus hundsheimensis, the elk Alces latifrons and the bison Bison schoetensacki (Table 2). The assemblage has overall similarities with preAnglian faunas in Britain e.g. Westbury-sub-Mendip (Andrews et al., 1999), of which few are known from fluvial sequences. The implied 'Cromerian Complex' age of this assemblage places it older than the entire Lower Thames sequence. 


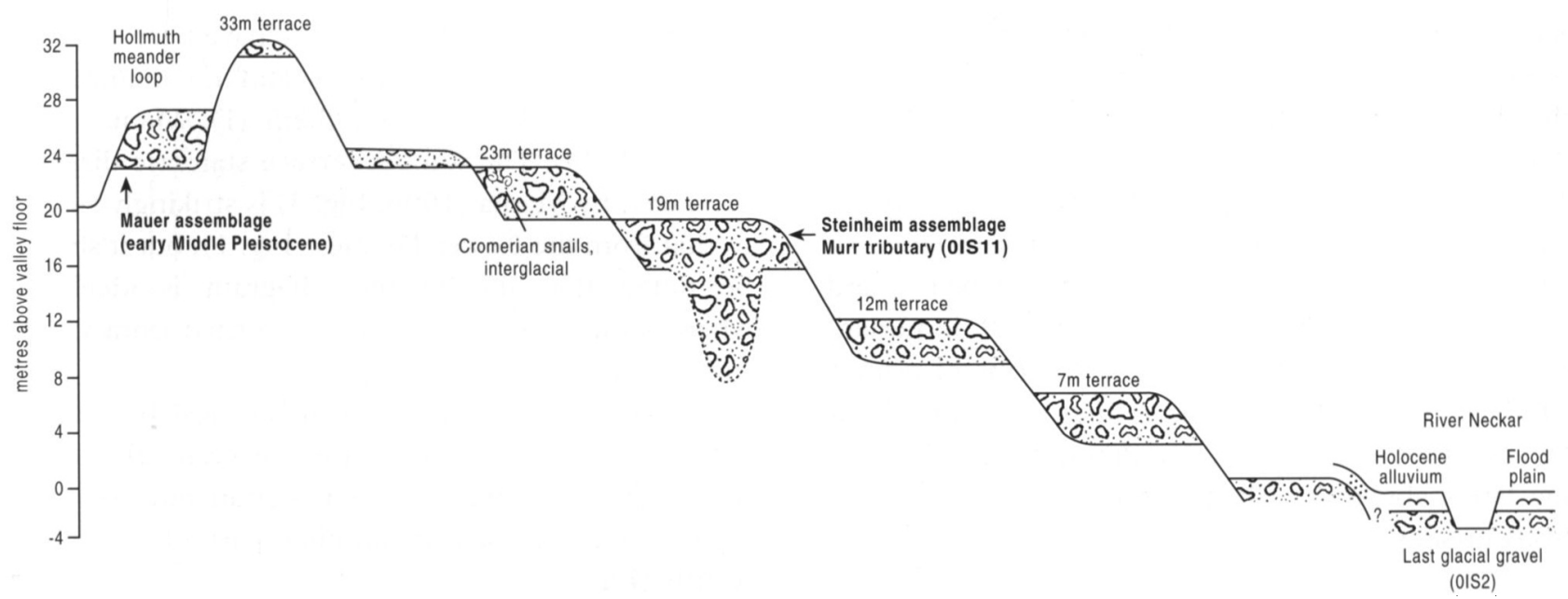

Fig. 3. Idealized terrace staircase of the Neckar, showing the stratigraphical positions of the Mauer and Steinheim mammal-bearing deposits. Modified from Bibus \& Wesler (1995).

However, the presence of straight-tusked elephant (Palaeoloxodon antiquus) (the first occurrence of this species) and Arvicola terrestris cantiana places the Mauer assemblage in the later part of the Cromerian Complex. A. t. cantiana, which is now known both from Germany and the UK to be present in the youngest two interglacials of the 'Cromerian Complex' (Van Kolfschoten \& Turner, 1996; Preece \& Parfit, 2000; Stuart \& Lister, 2001), replaced the ancestral water vole Mimomys savini, which characterizes earlier assemblages, such as that from the Cromerian type locality at West Runton. The presence of Cromerian molluscan taxa in the terrace (the $23 \mathrm{~m}$ Terrace) below the Mauer level (Bibus \& Wesler, 1995; Fig. 3) implies that the Mauer deposits do not represent the most recent part of the 'Cromerian Complex'. Mauer may therefore represent the earlier of the two interglacials with Arvicola, perhaps equivalent to OIS 15.

\section{River Murr: Steinheim, near Stuttgart}

The Steinheim site lies in the valley of the River Murr, a tributary of the Neckar (Fig. 2). Well known as a hominid fossil locality, Steinheim has frequently been compared with the British hominid site of Swanscombe and has generally been correlated with the Holsteinian Interglacial. The stratigraphical sequence consists of up to $22 \mathrm{~m}$ of gravels that have been subjected to differential faulting, the result of tectonic activity. Four subdivisions have been recognized within the gravel on the basis of changes in the elephant fauna: the trogontherii-Schotter (oldest), the antiquus-Schotter, the trogotherii-primigenius-Schotter and the primigenius-Schotter (youngest) (Adam, 1954). The majority of vertebrate remains come from the antiquus-Schotter and the assemblage from this level (Table 2) bears strong similarities to that from Swanscombe in terms of species composition. Biostratigraphically significant taxa in common include $S$. kirchbergensis, $S$. hemitoechus, $U$. spelaeus and a hominid with pre-Neanderthal characters, attributed to Homo steinheimensis by Berckhemer (1936). In addition, the antlers of $M$. giganteus from Steinheim possess a narrow span on account of their relatively upright orientation, when compared to later populations of giant deer (Lister, 1994). The Steinheim specimens also possess unusually expanded, almost circular brow tines, which have not been observed in any later giant deer. Although the antler bases of $M$. giganteus from Swanscombe are all incomplete, measurements of the width of the brow tine base where it inserts on the beam reveal the same broadness as seen in the Steinheim specimens, a feature of potential biostratigraphical significance (Lister, 1994). An interesting southern element of the fauna that is present at Steinheim and at several other Holsteinian localities in Germany is the water buffalo (Bubalus murrensis) (Von Koenigswald, 1986). This animal has not to date been recorded from any Pleistocene deposit in the UK, perhaps because its range did not extend so far to the west. The antiquus-Schotter is overlain by the trogotherii-primigenius-Schotter, which marks the appearance of a woolly mammoth attributed to the subspecies Mammuthus primigenius fraasi. The assemblage is less diverse than that from the underlying interglacial gravels, with horse, bison (Bison priscus) and red deer (Cervus elaphus) particularly well-represented. This assemblage, which has been assigned to the early Rissian (Adam, 1954), could represent the first cold episode after the Anglian/Elsterian, possibly OIS 10 , with the underlying interglacial levels attributed to OIS 11 .

Comparison of the stratigraphical position of the 
Steinheim deposits within the Neckar/Murr terrace sequence with that of the Swanscombe sediments in the Thames strengthens the suggested correlation. The terrace sediments at Steinheim, aggraded to $c$. $18 \mathrm{~m}$ above the valley floor, would seem to equate with the $19 \mathrm{~m}$ terrace of the Neckar system (Fig. 3), which is the fourth terrace counting upwards and which lies below the terrace containing 'Cromerian' shells (see above). This situation, in terms of terrace stratigraphy, is very similar to that encountered at Swanscombe (Figs 1 and 3), although the height of the latter above the Thames floodplain is comparatively greater.

\section{RiverWipper: Bilzingsleben, Thüringen}

Mania (1996, 1998) has described and illustrated a terrace staircase from this tributary stream of the Saale-Elbe system, preserved in the neighbourhood of Bilzingsleben (Figs $2 \& 4$ ).

The record from the Wipper is remarkable in that interglacials are represented by sub-aerially precipitated calcium carbonate travertine deposits in which the preservation of faunal and floral remains is excellent. The principal work to date has been carried out at the Bilzingsleben II terrace level, which has yielded significant early Palaeolithic assemblages as well as palaeontological evidence. These have been the subject of long-term archaeological investigations (Mania et al., 1980; Mai et al., 1983; Mania \& Weber, 1986; Fischer et al., 1991). Unfortunately the travertines of the lower terraces in the sequence have been exposed only in temporary excavations and no mammalian faunas are yet known from them (D. Mania, pers. comm., 2000). The Wipper terrace staircase diagram produced by Mania (1996; Fig. 4) is strikingly similar to that from the Lower Thames (Fig. 1), but it should be noted that the Thames diagram is idealized, whereas the Wipper diagram is recorded from an actual transect.

The entire terrace sequence at Bilzingsleben can be demonstrated to post-date the Elsterian glaciation, based upon the presence of Elsterian outwash in a higher $(35 \mathrm{~m})$ terrace in another part of the valley nearby (Fig. 4).

The earliest interglacial deposits, those represented by Bilzingsleben I, contain a molluscan assemblage including Theodoxus serratiliniformis. This species is a key biostratigraphical indicator for the first postAnglian interglacial in Britain, since it appears at Swanscombe as part of the exotic 'Rhenish' suite during a period of confluence between the Rhine and the Thames (Kerney, 1971). Although the stratigraphical range of this species is not firmly established on the continent (R.C. Preece, pers. comm., 2001), its presence has been taken to indicate a Holsteinian age, for example at Herzeele in NW France and Lo in SW Belgium (Meijer, 1988). The attribution of Bilzingsleben $I$ to the post-Elsterian period is further supported by the presence of $S$. kirchbergensis in the sparse mammalian assemblage from this level, since this species is unknown prior to the Anglian/Elsterian.

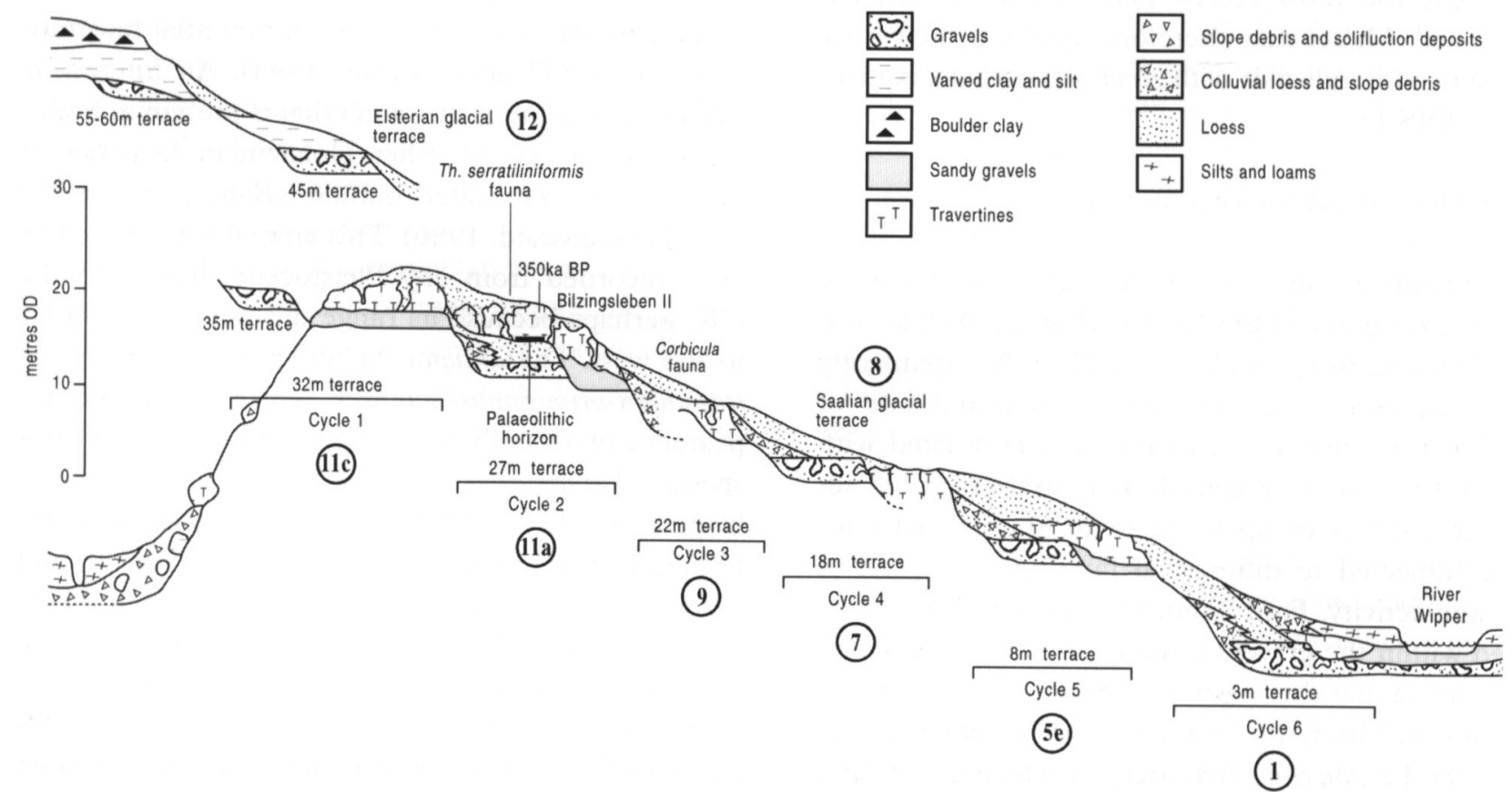

Fig. 4. Terrace staircase of the River Wipper at Bilzingsleben, showing the distribution of interglacial travertines, the stratigraphical position of glacio-fluvial inputs and key biostratigraphical levels. OIS correlations are suggested (circled). Modified from Mania (1996). 


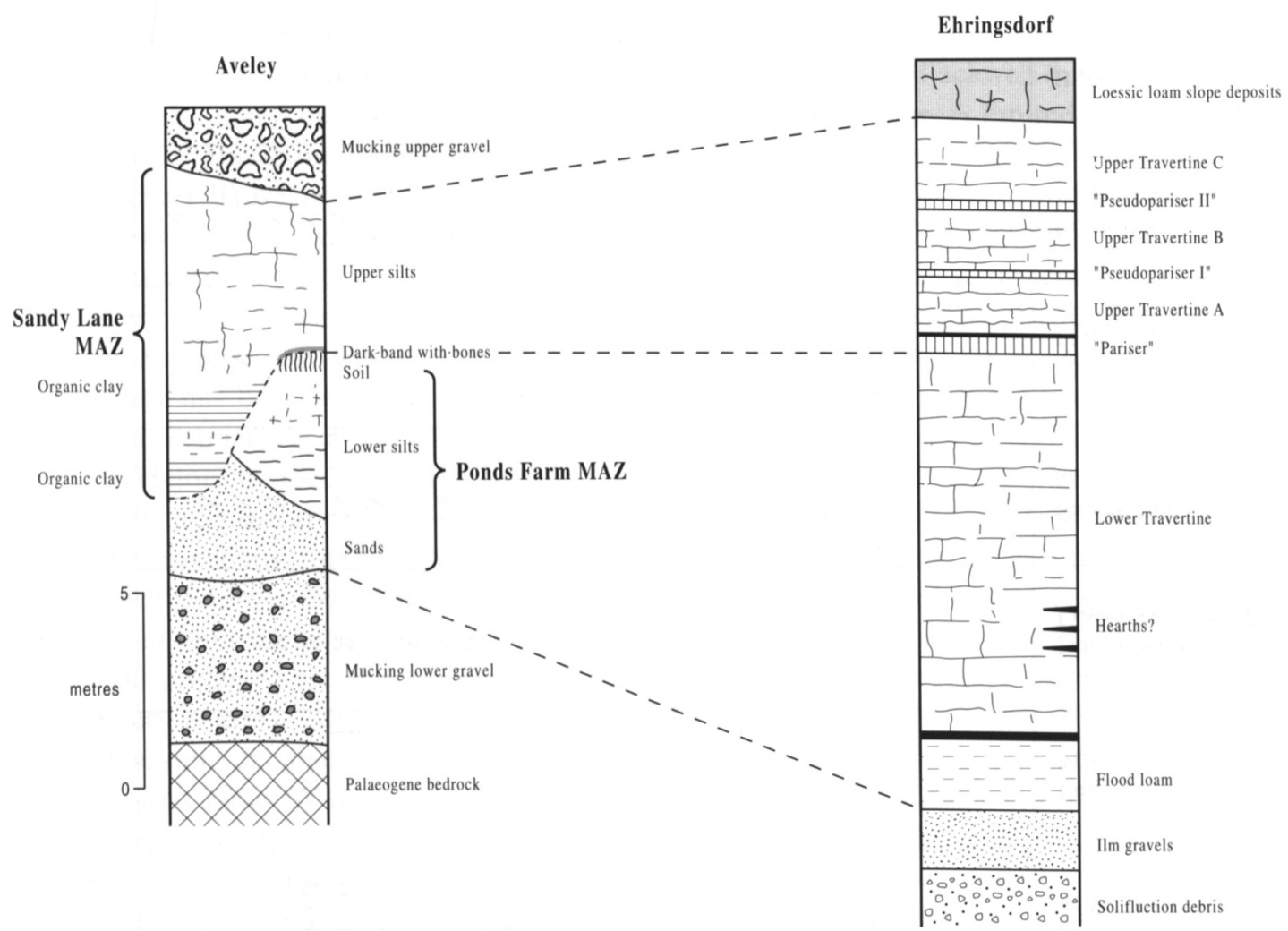

Fig. 5. Comparison of sedimentary sequences attributed to OIS 7 at Ehringsdorf and and Aveley (see text), showing stratigraphical positions of mammalian evidence and suggested correlation. Dashed lines indicate suggested points of correlation.

The mammalian assemblage from the second terrace, Bilzingsleben II (Fischer et al., 1991), the principal faunal and archaeological horizon at the locality, bears very strong similarities to British Swanscombe MAZ (OIS 11) faunas, in particular the co-existence of $U$. spelaeus, D. d. clactoniana, S. kirchbergensis, $S$. hemitoechus, A. t. cantiana, T. cuvieri and M. sylvanus (Table 2). Uranium series and ESR dating of the Bilzingsleben II main archaeological horizon is also consistent with an age within OIS 11 (Schwarcz et al., 1988). It is thus apparent that more than one set of temperate deposits at Bilzingsleben may be attributable to this warm isotope stage (Fig. 4) and it is tempting to suggest that climatic variability might be represented here at the oxygen isotope substage level, as at Swanscombe (Schreve, 2001b). Bilzingsleben I might therefore be correlated with an earlier substage of OIS $11(11 \mathrm{c})$ and Bilzigsleben II with a younger one (11a). The correlation of Bilzingleben I and II with OIS 11 provides an important fixed point for the dating of the lower terraces of the Wipper, pending the recovery of mammalian assemblages from those deposits. Even without mammalian faunal evidence, it is possible to suggest ages for the lower terrace deposits of the Wipper based on their lithostratigraphy, particularly since travertine deposition can only have occurred during interglacials (Mania, 1996). As with the Thames, it is clear that climatically driven terrace formation has taken place in an uplifting area, the rate of incision being similar in the two widely separated systems (both c. $0.07 \mathrm{~m} \mathrm{Ka}^{-1}$, perhaps implying comparable uplift histories (cf Maddy, 1997). The mammalian biostratigraphy offers the means not only of correlating the Thames and Wipper sequences but also of providing a dating context for the archaeology and hominid fossils from both. An interesting implication of this correlation is that the Saalian glacial input into the Wipper occurs at a level indicative of an OIS 8 age (cf Kukla, 1975, 1977; Bowen et al., 1986; Bridgland et al., 1997), rather than the OIS 6 age for that glaciation that is generally favoured (cf. De Jong, 1988). Indeed, it seems clear that the multiple Saalian advances into the Netherlands took place wholly within OIS 6 (Turner, 2000), but the possibility that, further east, earlier glaciations have been conflated with that of OIS 6 remains open (cf. Litt \& Turner, 1993).

\section{River Ilm:Weimar-Ehringsdorf, Thüringen}

The fluvial terrace sediments of the River Ilm also include interglacial travertine deposits yielding important mammalian assemblages, one of the best known of which is from Weimar-Ehringsdorf (Fig. 2). Here the sequence (Fig. 5) comprises Ilm gravels at the base, overlain by $2 \mathrm{~m}$ of floodloam, and then by up to 


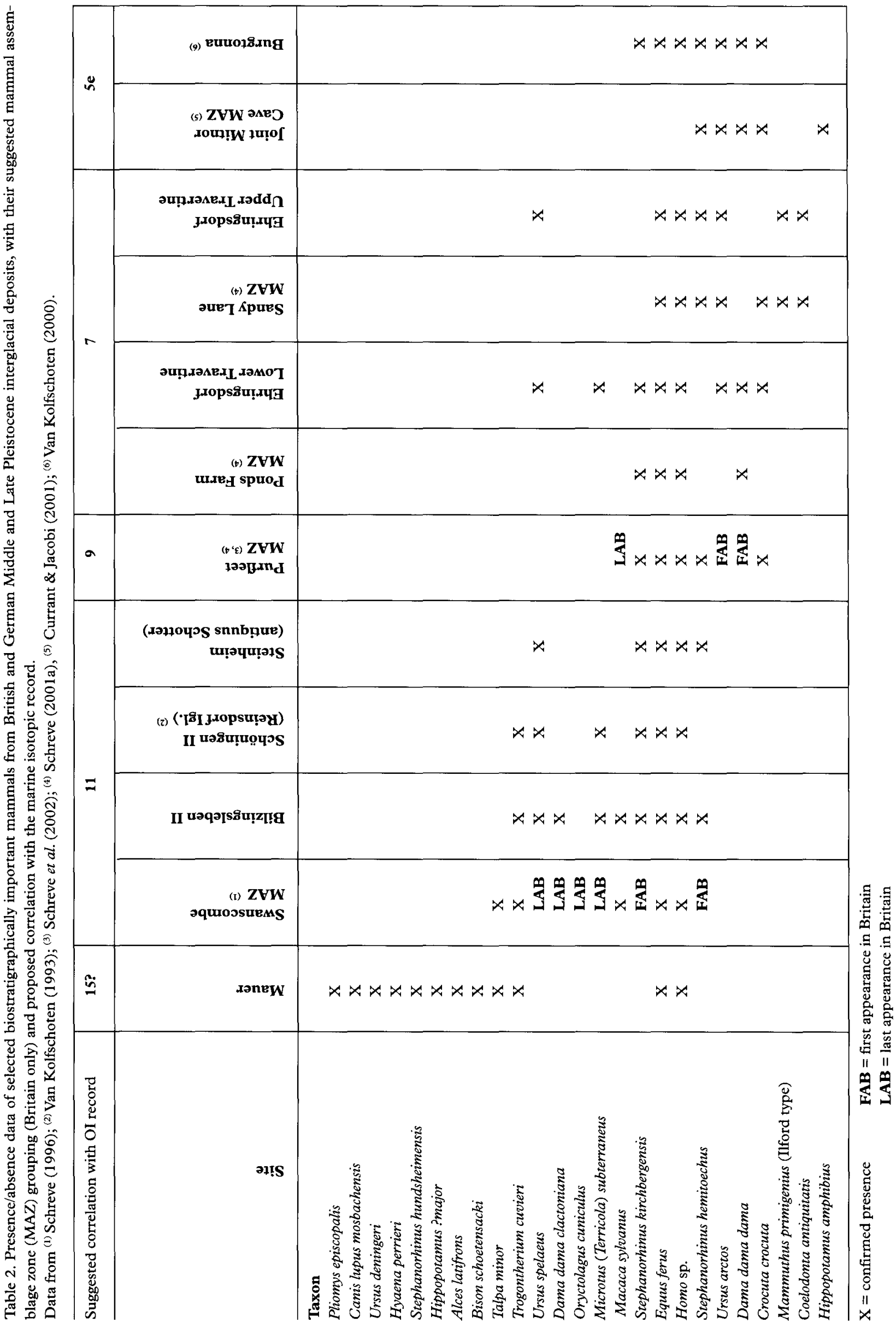


$15 \mathrm{~m}$ of Lower Travertine yielding rich faunal and floral remains, Middle Palaeolithic artefacts, evidence of hearths and human remains (Fig. 5).

The Lower Travertine is separated from a less coherent Upper Travertine by a loess-rich unit, the 'Pariser' layer, within which a soil is developed. The Upper Travertine is broken up by three 'pseudopariser' layers and has also yielded a rich faunal assemblage. The age of the sequence exposed at WeimarEhringsdorf has been the subject of lengthy debate, with both Eemian (Kahlke, 1974, 1975) and preEemian (Heinrich, 1982; Von Koenigswald \& Heinrich, 1999) ages advanced for all or part of the deposits. Most recently, there has been a growing acceptance that the Lower Travertine may well represent a pre-Eemian interglacial episode, although an Eemian age is still preferred for the Upper Travertine (R.D. Kahlke pers. comm., 2000).

Comparison of mammalian assemblages from Ehringsdorf (Table 2) with those from the Thames suggests that both the Lower and Upper Travertine at the former site could potentially be placed within the OIS 7 interglacial. A pre-Eemian age for the Lower Travertine is supported by biometrical evidence from a number of mammalian groups. Measurements of the third upper molar (M3) have been taken on three large samples of $S$. kirchbergensis from Thüringen, namely Bilzingsleben (see above), Ehringsdorf and Taubach (Van der Made, 2000), the latter widely regarded as being of Eemian age, Brunnaker et al., 1993). The results demonstrate an evolutionary trend throughout the late Middle and late Pleistocene towards an increasingly large M3, with the Ehringsdorf sample occupying an intermediate position between Bilzingsleben and Taubach. Such an increase in the size of the $M 3$ relative to other teeth is very common among ungulates and is thought to be an adaptation to a progressively inferior-quality diet (Van der Made, 1999). These findings are consistent with a pre-Eemian age for the Ehringsdorf sequence, thereby corroborating earlier suggestions to this effect based upon indices of morphological development in Arvicola molars (Heinrich, 1982) and incisors of European beaver (Castor fiber) (Heinrich, 1989).

As at Aveley and its close correlative at Ilford, the $M$. primigenius sample from the Upper Travertine at Ehringsdorf contains individuals that may be assigned to the 'Ilford type' mammoth, a biostratigraphical indicator for the Sandy Lane MAZ (OIS 7) in Britain. This is taken to be an important diagnostic element of the penultimate interglacial, at least in this part of Germany, since it is not recorded from classic Eemian sites in the region, such as Burgtonna (see Table 2) or Taubach (Van Kolfschoten, 2000). Uranium-series age-estimates from the Lower Travertine of 225 $\pm 28 \mathrm{Ka}$ (Blackwell \& Schwarcz, 1985) also support an OIS 7 age. A limited vertebrate assemblage has been recovered from the intermediate Pariser horizon, amongst which the presence of thermophilous taxa such as E. orbicularis indicates that temperate climatic conditions persisted. There is no evidence in the Ehringsdorf sequence for the severe glacial that correlates with OIS 6 , thereby appearing to support the notion that only a single interglacial is represented.

The closest correlative in the Thames is the sequence from Aveley (see above and FigureFig. 5). Both Aveley and Ehringsdorf show precisely the same patterns of faunal turnover, with an earlier woodlanddominated fauna replaced by a more open grassland fauna midway through an interglacial. At Ehringsdorf, the forest-adapted $S$. kirchbergensis is successively replaced from the middle of the Lower Travertine by the grassland-adapted $S$. hemitoechus and is absent in the Upper Travertine. The Upper Travertine also marks the first occurrence of woolly rhinoceros (Coelodonta antiquitatis). Similarly, $P$. antiquus, which was present in the Lower Travertine, is completely replaced in the Upper Travertine by $M$. primigenius. Striking parallels are present in British sequences, with $S$. hemitoechus, $C$. antiquitatis and $M$. primigenius dominating late OIS 7 interglacial assemblages at the expense of $S$. kirchbergensis and $P$. antiquus (Schreve, 1997, 2001a). The changes in the mammalian fauna are thought to reflect climatic and environmental oscillations within the interglacial, similar to those observed in Britain. The cumulative lines of evidence thus favour a pre-Eemian OIS 7 age for both Lower and Upper travertines.

\section{Unknown river(s): Schöningen, near Magdeburg}

The celebrated sequence from the Schöningen lignite mine (Fig. 2) (Thieme \& Maier, 1995; Urban, 1995; Urban et al., 1995) includes fluvial sediments laid down in a subsiding graben adjacent to a salt-dome. The lower part of the sequence, including the lignite, is Palaeogene, but the uppermost levels have provided an extremely important Quaternary sequence. Between Elsterian and Saalian (Drenthe) glacial sediments three superimposed (actually overlapping) interglacial fluvial channel sequences have been described. These are identified respectively as Holsteinian (Schöningen I), Reinsdorf interglacial (II) and Schöningen interglacial (III). All three channels have provided pollen records, although vertebrate remains have, to date, been described only from the Reinsdorf interglacial (Van Kolfschoten, 1993; Table 2). 
The Reinsdorf interglacial is represented by fossiliferous organic muds and peats with numerous deformation structures. Important archaeological remains have been recovered from them (Thieme, 1997, 1999), including several worked branches of common silver fir (Abies alba), together with eight wooden spears, made from the heartwood of spruce (Picea), as opposed to the spear point from Clacton (Anon., 1911; McNabb, 1989), which is made of yew (Taxus). The mammalian assemblage most closely resembles those from Bilzingsleben II and Swanscombe. It is dominated by $E$. ferus (probably the target of selective hunting by contemporary hominids) with $T$. cuvieri, $A$. t. cantiana, $U$. spelaus and $S$. kirchbergensis also recorded (Van Kolfschoten, 1993; Table 2). There is considerable disagreement, however, over the age of these deposits. According to Mania (1996), the palynological evidence supports correlation with Bilzingsleben II and favours an age towards the end of OIS 11 , although an alternative interpretation, proposing equivalence of the Reinsdorf interglacial with OIS 9, has been put forward by Urban (1995; Urban et al., (1995). However, the Purfleet MAZ of OIS 9 contains taxa such as $C$. crocuta and $U$. arctos that one might reasonably expect to be represented in continental faunas of equivalent age and so, on the basis of the mammalian biostratigraphical evidence, correlation with OIS 11 is favoured here.

\section{Discussion}

Table 2 summarizes the mammalian data discussed in this paper. It should be viewed against the background of the mammalian biostratigraphical scheme for Britain established by Schreve (1997, 2001a) and Bridgland \& Schreve (2001). It had been suspected that periodic insularity might have enhanced the distinctive character of British temperate-climate mammalian assemblages through the failure of species to reach Britain before separation from the continent occurred. However, the results gathered in the Leverhulme-funded project indicate that, in the majority of cases, insularity is not an important factor. For example, the absence of $C$. crocuta from British Swanscombe MAZ/OIS 11 sites is paralleled on the European mainland in Holsteinian localities. While it is evident that some extinct species persisted on the continental mainland longer than they did in Britain (eg. U. spelaeus), and that certain extant European taxa are no longer native to Britain (eg. M. subterraneus), a good correspondence was noted between the continental assemblages examined and those from Britain, allowing correlation of the interglacials concerned to be made with some confidence.
Particularly convincing is the correlation between the travertine deposits at Weimar-Ehringsdorf and the numerous British sites attributed to OIS 7 . This is a significant advance, since the Ehringsdorf site has, like many British sites now attributed to OIS 7, long been regarded as of Last Interglacial (Eemian) age. Also highly convincing is the comparison of Bilzingsleben II and Steinheim an der Murr with sites attributed to the British Hoxnian, equated with OIS 11 (Table 2). This serves to confirm or perhaps re-establish the correlation between the British Hoxnian and the continental Holsteinian. Stuart (1995) suggested that such faunal continuity provided little evidence of insularity, although it is far from certain that a terrestrial connection persisted between the two regions for any length of time. Although such a link is clearly demonstrated at Swanscombe by the arrival of the 'Rhenish' molluscan suite midway through the interglacial, the land connection was subsequently severed by marine transgression. Evidence for this transgression has been observed at several sites in southern Britain, in sediments covering pollen subzone Ho IIIa - Ho IIIb, most notably at Clacton (Turner \& Kerney, 1971) and at East Hyde (Roe \& Preece, 1995). There is also tentative support for island status early in the interglacial, hinted at by the presence of stenohaline and diadromous euryhaline fish in early interglacial sediments at Swanscombe (Irving, 1996). A possible cause of this early Hoxnian transgression, which did not reach the present land area of SE England, might be the persistence of Elsterian/Anglian glacio-isostatic crustal depression (Kukla \& Cílek, 1996), with the reconnection noted above caused by isostatic recovery, prior to the eventual high-sea-level peak much later in the interglacial (White \& Schreve, 2000).

One clear difference is, however, apparent between Britain and Germany in terms of their Eemian/ Ipswichian mammal faunas. The British Last Interglacial is characterized by the unequivocal absence of E. ferus, Homo and S. kirchbergensis, yet all three are known from eastern Germany during the Eemian (Table 2, Van Kolfschoten, 2000). The reasons for this remain poorly understood but it seems likely that they failed to re-colonise Britain from the continental mainland before a rise in sea level removed the access route (cf. Von Koenigswald, 1992). Furthermore, there appears to be no bona fide evidence of human occupation at this time in the Netherlands, western Belgium or northern France. Sites considered by Speelers (2000) to provide such evidence include four on the Cotentin peninsula in Normandy (France) and the cave site of Sclayn in Belgium, although none are unambiguous in terms of their age. 
It is therefore possible that during the Eemian, human occupation occurred no closer to the British Isles than central and eastern Germany.

There remain a number of uncertainties. At Schöningen, the preferred correlation of the Reinsdorf Interglacial has been with OIS 9 and the Schöningen interglacial with OIS 7 (Urban, 1995) but this is largely governed by the adherence of the workers there to a correlation scheme in which the Elsterian glaciation is thought to date from OIS 10 . Adopting the correlation scheme favoured by the present authors, in which the Elsterian/Anglian is correlated with OIS 12 , it is possible to view the same two sets of deposits at Schöningen as equivalent to OIS 11 and OIS 9, respectively. The present interpretation would place both the Schöningen I (Holsteinian) and Schöningen II (Reinsdorf) deposits in OIS 11 and would consequently suggest that separate intra-stage warm-climatic fluctuations are represented there, as is the case at Swanscombe and Bilzingsleben (see above). The significance of separate warm substages within OIS 11 has been confirmed by data from a continuous pollen record in Greece (Tzedakis \& Bennett, 1996; Tzedakis et al., 2001), so their separate identification within the three fluvial sequences described here would not be unexpected. Climatically driven erosion during the warming transition leading to each warm substage may well have led, in the subsiding area at Schöningen, to representation in separate overlapping channels, in contrast to areas where river terraces have formed, such as the Thames valley. In the Thames there is evidence for breaks in the sequence representing fluvial response at the oxygen isotope substage level, again the result of climatically driven erosion, but the sediments from each stage form part of the same terrace complex (e.g. Swanscombe and Aveley - see above).

Mammalian evidence from both the Holsteinian and Reinsdorf channels at Schöningen is consistent with OIS 11, as opposed to any younger age, based upon the comparability of the assemblages with British Hoxnian localities. Also of potential significance to this debate is the occurrence of Azolla filliculoides in all three of the pre-Saalian channels at Schöningen (I, II and III). This aquatic plant has never been found in last interglacial or OIS 7 contexts (cf Godwin, 1975). Its presence in the Schöningen interglacial (Schöningen III) would seem to support the OIS 9 interpretation of that episode favoured here. Urban (1995), however, reported that the Schöningen III sediments contained no Abies pollen, whereas this species is important at sites in Britain now attributed to OIS 9, such as Cudmore Grove (Roe, 1999).

This debate is further linked to the questionable age of the Maastricht-Belvédère deposits in the Netherlands (Van Kolfschoten et al., 1993), since a correlation has been suggested (Vandenberghe, 1995) between the Belvédère interglacial at the latter site and the early-middle part of the Schöningen interglacial (Schöningen III). It is interesting to note, in this respect, that amino acid analyses of post-Elsterian temperate-climate molluscan shells from the Netherlands have revealed four separate groups of ratios, conceivably representing the same four temperate-climate episodes recognized in the Lower Thames (Meijer \& Preece, 2000). Ratios from shells collected at Maastricht-Belvédère place the interglacial sediments there in the second-oldest of these groups. In the "short-chronology" (Dutch) scheme, in which the Elsterian is correlated with OIS 10, the four temperate-climate episodes are identified as OIS $9,7 \mathrm{c}, 7 \mathrm{a}$ and $5 \mathrm{e}$. Maastricht-Belvédère has been attributed to OIS 7c, a warm episode of short duration, correlated with the Hoogeveen Interstadial (Zagwijn, 1973; Van Kolfschoten et al., 1993; Vandenberghe, 1995). In the 'long-chronology' scheme favoured here, in which the Elsterian/Anglian is correlated with OIS 12, this second-oldest post-Anglian interglacial is equated with OIS 9. Correlation of MaastrichtBelvédère with Schöningen III would thus conform with an OIS 9 age for the Schöningen interglacial. This interpretation, like that of the Wipper sequence (see above), would place the Saalian glaciation of this part of Germany in OIS 8 (cf. Bridgland et al., 1997). It should also be noted that in Britain, in addition to a separate OIS 9 interglacial, the sequence at Aveley, representing the next youngest post-Anglian interglacial in the Thames sequence, contains at least two, and possibly three, discrete temperate-climate episodes (Schreve, 1997, 2001a, 2001b), which may well turn out to be the equivalent of the various substages of OIS 7. This would appear to uphold the longer chronology model for the late Middle Pleistocene and would consequently advocate correlation of the Anglian/Elsterian with OIS 12.

\section{Conclusion}

It is apparent that the late Middle Pleistocene mammalian record from the Lower Thames is at present unequalled elsewhere in NW Europe. The evidence from central Germany, from the travertines of Thüringen and the superimposed channel-fills at Schöningen, provides the best potential comparison. Elsewhere it is a case of isolated sites providing assemblages from just a small part of the palaeoclimatic sequence represented in the Thames, usually just one of the three late Middle Pleistocene interglacials rec- 
ognized in Britain. The tremendous value of the Thames sequence is underlined by this realisation; comparison with the mammalian assemblages from the Thames, where each occurs within the stratigraphical constraints of the river terrace staircase, can enable identification of the interglacial episodes represented in isolated sites elsewhere. This is true of sites representing non-fluvial as well as fluvial environments. The remaining doubt centres on the possible exceptional status of Britain's fauna during interglacials, because of insularity. The similarity of assemblages from the Thames attributed to OIS 11 and OIS 7 to German faunas believed to represent the same episodes (see above) provides the first indication that this is not a significant problem. Thus far an OIS 9 fauna has not been recognized unequivocally at a continental fluvial locality, although there is potential for identifying such an assemblage at Bilzingsleben, from the travertine associated with the next terrace below the Bilzingsleben II level (see FigureFig. 4). The same interglacial is surely represented within the Schöningen sequence, although details of all the interglacial faunas from that site are as yet unavailable. It is also possible that the Dutch site of Maastricht-Belvédère represents the OIS 9 interglacial, rather than the OIS 7 age favoured by workers in the Netherlands. Deciding which of the British (Anglian/Elsterian $=$ OIS 12) or the Dutch (Elsterian/Anglian $=10$ ) schemes for correlating Middle Pleistocene terrestrial sequences with the marine oxygen isotope record is correct is one of the most important unanswered questions in Quaternary science in Europe.

\section{Acknowledgements}

The authors are extremely grateful to the Leverhulme Trust for funding the project as a result of which much of the data presented here has been compiled. Danielle Schreve also acknowledges a Research Studentship from the Biotechnology and Biological Sciences Research Council (BBSRC). The authors have benefited from fruitful discussion with Mr A.P. Currant, Dr. R.-D. Kahlke, Dr. T. Van Kolfschoten, Dr. D. Mania, Dr. L.C. Maul, Dr. R.C. Preece and Dr. R. Ziegler. Danielle Schreve thanks Dr. D. Frey of the Staatliches Museum für Naturkunde in Karlsruhe for access to the Mauer collections, Dr. R. Ziegler at the Staatliches Museum für Naturkunde in Stuttgart for access to the Steinheim collections and Dr. R.-D. Kahlke and Dr. L.C. Maul of the Institut für Quartärpaläontologie (Forschungsinstitut und Naturmuseum Senckenberg) in Weimar for access to the Ehringsdorf collections.
This paper represents a contribution to IGCP 449 'Global Correlation of Late Cenozoic fluvial deposits'

\section{References}

Adam, K.D., 1954. Die mittelpleistozänen Faunen von Steinheim an der Murr (Württemberg). Quaternaria 1: 131-144.

Andrews, P, Cook. J., Currant, A. \& Stringer, C., 1999. Westbury Cave. The Natural History Museum Excavations 1976-1984. Western Archaeological and Specialist Press. University of Bristol: $309 \mathrm{pp}$.

Anon., 1911. Exhibition by S.H.Warren of plaster casts of Palaeolithic wooden spear (?) and some flint-flakes from a Pleistocene deposit at Clacton-on-Sea. Essex Naturalist, 16: 326.

Anon., 1966. Note on the Aveley elephants. Report of the British Museum (Natural History) 1963-1965: 30-31.

Berckhemer, F., 1936. Die Urmenschenschädel aus den zwischeneiszeitlichen Fluß-Schottern von Steinheim an der Murr. Forschungen und Fortschritte 12: 349-350.

Blackwell, B. \& Schwarcz, H.P., 1986. U-Series analyses of the Lower Travertine at Ehringsdorf, DDR. Quaternary Research 25: 215-222.

Bibus, E. \& Wesler, J., 1995. The middle Neckar as an example of fluviomorphological processes during the Late Quaternary Period. Zeitschrift für Geomorphologie N.F. Supplement Band 100: 15-26.

Bosinski, G., 1996. The earliest occupation of Europe: Western Central Europe. In: Roebroeks, W. \& Van KolfschotenVan Kolfschoten, T. (eds): The Earliest Occupation of Europe. University of Leiden: 103-128.

Bowen, D.Q. (ed.), 1999. A revised correlation of Quaternary deposits in the British Isles. Geological Society Special Report 23 (London): $174 \mathrm{pp}$.

Bowen, D.Q., Richmond, G.M., Fullerton, D.S., Sibrava, V., Fulton, R.J. \& Velichko, A.A., 1986. 1986. Correlation of Quaternary glaciations in the Northern Hemisphere. Quaternary Science Reviews 5: 509-510 + loose figures.

Bowen, D.Q., Hughes, S., Sykes, G.A. \& Miller, G.H., 1989. Landsea correlations in the Pleistocene based on isoleucine epimerisation in non-marine molluscs. Nature 340: 49-50.

Bridgland, D.R., 1994. Quaternary of the Thames. Chapman and Hall (London): $441 \mathrm{pp}$.

Bridgland, D.R., 1995. The Quaternary sequence of the eastern Thames basin: problems of correlation. In: Bridgland, D.R., Allen, P. and \& Haggart, B.A. (eds.): The Quaternary of the lower reaches of the Thames. Field Guide. Quaternary Research Association (Durham): 35-49.

Bridgland, D.R., 2000. River terrace systems in north-west Europe: an archive of environmental change, uplift and early human occupation. Quaternary Science Reviews 19: 1293-1303.

Bridgland, D.R. \& Harding, P., 1994. Lion Pit tramway cutting, West Thurrock. In: Bridgland, D.R., 1994. Quaternary of the Thames. Chapman and Hall (London): 237-251.

Bridgland, D.R. \& Maddy, D., 1995. River Terraces as records of Quaternary Climate Oscillation. Programme with Abstracts. INQUA XIV. Berlin: 37.

Bridgland, D.R. \& Schreve, D.C., 2001. River terrace formation in synchrony with long-term climatic fluctuation: examples from SE England. In: Maddy, D, Macklin, M. \& Woodward, J. (eds) eds): River Basin Sediments Systems: Archives of Environmental Change. Balkema (Rotterdam): 229-248.

Bridgland, D.R., Schreve, D.C., Lewis, S.G. \& Currant, A.P., 1997. Important faunal sites of the Pleistocene of Germany, 27th May - 1st June 1996. Quaternary Newsletter 81: 26-36. 
Bridgland, D.R., Field, M.H., Holmes, J.A., McNabb, J., Preece, R.C., Selby, I. \& Wymer, J.J., 1999. Middle Pleistocene interglacial Thames-Medway deposits at Clacton-on-Sea, England; reconsideration of the biostratigraphical and environmental context of the type Clactonian Palaeolithic industry. Quaternary Science Reviews, 18: 109-146.

Brunnaker, K., Jäger, K.D., Hennig, G.J., Preuss, J. \& Grün, R., 1993. Radiometrische Untersuchungen zur Datierung mitteleuropäischer Travertinvorkommen. Ethnographisch-Archäologische Zeitschrift 24: 217-266.

Currant, A.P., 1989. The Quaternary origins of the modern British mammal fauna. Biological Journal of the Linnean Society 38 : 23-30.

Currant, A.P. \& Jacobi, R.M., 2001. A formal mammalian biostratigraphy for the Late Pleistocene of Britain. Quaternary Science Reviews 20/16-17: 1707-1716.

Ehlers, J., Gibbard, P.L. \&, Rose, J. (eds): 1991. Glacial deposits in Great Britain and Ireland. Balkema (Rotterdam): Balkema: 580 pp.

Fischer, K., Guenther, E.W., Heinrich, W.D., Mania, D., Musil, R. \& Nötzold, T., 1991. Bilzingsleben IV. Veröffenlichungen Landesmuseum fürVorgeschichte Halle 44 (Berlin): $248 \mathrm{pp}$.

Franks, J.W., Sutcliffe, A.J., Kerney, M.P. \& Coope, G.R., 1958. Haunt of elephant and rhinoceros: the Trafalgar Square of 100,000 years ago - new discoveries. The Illustrated London News June 14: 1011-1013.

Gibbard, P.L., 1994. Pleistocene History of the Lower Thames Valley. Cambridge University Press: 229 pp.

Gibbard, P.L., 1995. Palaeogeographical evolution of the Lower Thames Valley. In: Bridgland, D.R., Allen, P. \& Haggart, B.A. (eds) eds): The Quaternary of the lower reaches of the Thames. Field Guide. Quaternary Research Association (Durham): 5-34.

Godwin, H., 1975. History of the British flora: a factual basis for phytogeography. Cambridge University Press, 2nd edition: $541 \mathrm{pp}$.

Harding, P. \& Gibbard, P.L., 1984. Excavations at Northwold Road, Stoke Newington, north east London, 1981. Transactions of the Middlesex Archaeological Society 34: 1-18.

Heinrich, W.-D., 1982. Zur Evolution und Biostratigraphie von $\mathrm{Ar}$ vicola (Rodentia, Mammalia) im Pleistozän Europas. Zeitschrift für Geologische Wissenschaften 10: 683-735.

Heinrich,W.-D., 1987. Neue Ergebnisse zur Evolution und Biostratigraphie von Arvicola (Rodentia, Mammalia) im Quartär Europas. Zeitschrift für Geologische Wissenschaften 15: 389-406.

Heinrich, W.D., 1989. Biometrische Untersuchungen an Fossilresten des Bibers (Castor fiber) aus thüringischen Travertinen. Ethnographisch-Archäologische Zeitschrift 30: 394-403.

Hollin, J.T., 1977. Thames interglacial sites, Ipswichian sea levels and Antarctic ice surges. Boreas 6: 33-52.

Irving, B., 1996. The ichthyofauna from the Waechter excavations, Barnfield Pit, Swancombe. In: Conway, B., McNabb, J. and \& Ashton, N. (eds) eds): Excavations at Barnfield Pit, Swanscombe, 1968-1972. Occasional Paper of the British Museum 94: 145-148.

De Jong, J., 1988. Climatic variability during the past three million years, as indicated by vegetational evolution in northwest Europe and with emphasis on data from the Netherlands. Philosophical Transactions of the Royal Society of London B318: 603-617.

Kahlke, H.-D., 1974. Das Pleistozän von Weimar-Ehringsdorf. Teil I. Abhandlungen der Zentralen Geologischen Institute, Paläontologische Abhandlungen 21:351 pp.

Kahlke, H.-D., 1975. Das Pleistozän von Weimar-Ehringsdorf. Teil II. Abhandlungen der Zentralen Geologischen Institute, Paläontologische Abhandlungen, 23: $594 \mathrm{pp}$.
Klostermann, J., 1995. Nordrhein-Westfalen. In: Benda, L. (ed.): Das Quartär Deutschlands. Gebrüder Borntraeger (Berlin): 5994.

Kukla, G.J., 1975. Loess stratigraphy of Central Europe. In: Butzer, K.W. \& Isaac, G.L. (eds) eds): After the Australopithecines. Mouton (The Hague): 99-188.

Kukla, G.J., 1977. Pleistocene land-sea correlations. I. Europe. Earth Science Reviews 13: 307-374.

Kukla, G. \& Cilek, V., 1996. Plio-Pleistocene megacycles: record of climate and tectonics. Palaeogeography, Palaeoclimatology, Palaeoecology 120: 171-194.

Lister, A.M., 1994. The evolution of the giant deer, Megaloceros giganteus (Blumenbach). Zoological Journal of the Linnean Society 112: 65-100.

Litt, T. \& Turner, C., 1993. Arbeitsergebnisse der Subkommission für Europäische Quartärstratigraphie: die Saalesequenz in der Typusregion (Berichte der SEQS 10). Eiszeitalter und Gegenwart 37: 145-148.

Maddy, D., 1997. Uplift-driven valley incision and river terrace formation in southern England. Journal of Quaternary Science 12: 539-545.

Maddy, D. \& Bridgland, D.R., 2000. Accelerated uplift resulting from Anglian glacioisostatic rebound in the Middle Thames valley, UK: evidence from the terrace record. Quaternary Science Reviews 19: 1589-1604

Mai, D.H., Mania, D., Nötzold, T., Toepfer, V., Vlcek, E. \& Heinrich, W.D., 1983. Bilzingsleben II. Veröffentlichungen Landesmuseum fürVorgeschichte Halle 36 (Berlin): $258 \mathrm{pp}$.

Mania, D., 1996. The earliest occupation of Europe: the Elbe-Saale region (Germany). In: Roebroeks, W. \& Van Kolfschoten, T. (eds): The Earliest Occupation of Europe. University of Leiden, The Netherlands: 85-101.

Mania, D., 1998. Zum Ablauf der Klimazyklen seit der Elstervereisung im Elbe-Saalegebiet. Praehistoria Thuringica 2: 5-21.

Mania, D. \& Weber, T., 1986. Bilzingsleben III. Veröffenlichungen Landesmuseum für Vorgeschichte Halle 39 (Berlin): 400 pp.

Mania, D., Toepfer, V. \& Vlcek, E., 1980. Bilzingsleben I. Veröffenlichungen Landesmuseum für Vorgeschichte Halle 32 (Berlin): $176 \mathrm{pp}$.

McNabb, J., 1989. Sticks and stones: a possible experimental solution to the question of how the Clacton spear point was made. Proceedings of the Prehistoric Society 55: 251-271.

Meijer, T., 1988. Fossiele Zoetwaternerieten uit het Nederlandse Kwartair en enkele opmerkingen over het voorkomen van deze groep in het Kwartair van Noordwest Europa. De Kreukel, Jubileumnummer: 89-109.

Meijer, T. \& Preece, R.C., 2000. A review of the occurrence of Corbicula in the Pleistocene of north-west Europe. Geologie en Mijnbouw/Netherlands Journal of Geosciences 79: 241-255.

Morris, J., 1836. On a freshwater deposit containing mammalian remains, recently discovered at Grays, Essex. Magazine of Natural History: Series 1 (9): 261-264.

Preece, R.C. \& Parfitt, S.A., 2000. The Cromer Forest-bed Formation: new thoughts on an old problem. In: Lewis, S.G., Preece, R.C. and \& Whiteman, C.A. (eds) eds): The Quaternary of Norfolk and Suffolk. Field Guide. Quaternary Research Association (London): 1-28.

Roe, H.M., 1999. Late Middle Pleistocene sea-level change in the southern North Sea: the record from eastern Essex, UK. Quaternary International 55, 115-128.

Roe, H.M. \& Preece, R.C., 1995. A new discovery of the Middle Pleistocene 'Rhenish' fauna in Essex. Journal of Conchology 35: 272-273.

Roebroeks, W. \& Van Kolfschoten, T., 1996. The Earliest Occupation of Europe: a reappraisal of artefactual and chronological 
evidence. In: Roebroeks, W. \& van KolfschotenVan Kolfschoten, T. (eds) eds): The Earliest Occupation of Europe. University of Leiden, 297-315.

Rowe, P.J., Atkinson, T.C., \& Turner, C., 1999. U-series dating of Hoxnian interglacial deposits at Marks Tey, Essex, England. Journal of Quaternary Science 14: 693-702.

Sarnthein, M., Stremme, H.E. \& Mangini, A., 1986. The Holstein interglaciation: Time-stratigraphic position and and correlations to the stable-isotope stratigraphy of deep-sea sediments. Quaternary Research 29:, 75-79.

Schreve, D.C., 1996. The mammalian fauna from the Waechter excavations, Barnfield Pit, Swanscombe. In: Conway, B., McNabb, J. \& Ashton, N. (eds): Excavations at Barnfield Pit, Swanscombe, 1968-1972. Occasional Paper of the British Museum, 94: 149162.

Schreve, D.C., 1997. Mammalian biostratigraphy of the later Middle Pleistocene in Britain. University of London, unpublished Ph.D. thesis, 776 pp.

Schreve, D.C., 2000. The vertebrate assemblage from Hoxne, Suffolk. In: Lewis, S.G., Preece, R.C. \&, Whiteman, C.A. (eds): The Quaternary of Norfolk and Suffolk. Field Guide. Quaternary Research Association (London): 155-164.

Schreve, D.C., 2001a. Differentiation of the British late Middle Pleistocene interglacials: the evidence from mammalian biostratigraphy. Quaternary Science Reviews 20/16-17: 1693-1705.

Schreve, D.C., $2001 \mathrm{~b}$. Mammalian evidence from fluvial sequences for complex environmental change at the oxygen isotope substage level. Quaternary International 79: 65-74.

Schreve, D.C., Bridgland, D.R., Allen, P., Blackford, J.J., GleedOwen, C.P., Griffiths, H.I., Keen, D.H. \& White, M.J., 2002. Sedimentology, palaeontology and archaeology of late Middle Pleistocene River Thames terrace deposits at Purfleet, Essex, UK. Quaternary Science Reviews, 21: 1423-1464.

Schwarcz, H.P., Grün, R., Latham, A.G., Mania, D. \& Brunnacker, K. 19., 1988. The Bilzingsleben Archaeological Site: New Dating Evidence. Archaeometry 30:5-17.

Scourse, J.D., Austin, W.E.N., Sejrup, H.P., Ansari, M.H., 1999. Foraminiferal isoleucine epimerization determinations from the Nar Valley Clay, Norfolk, UK: implications for Quaternary correlations in the southern North Sea basin. Geological Magazine 136: 543-560.

Shackleton, N.J., 1987. Oxygen isotopes, ice volume and sea level. Quaternary Science Reviews 6: 1835-1890.

Shotton, F.W., 1983. United Kingdom contribution to the I.G.C.P.; Project 24, Quaternary Glaciations of the Northern Hemisphere. Interglacials after the Hoxnian in Britain. Report by a working group chaired by Professor F.W. Shotton. Quaternary Newsletter, 39: 19-25.

Speleers, B., 2000. The relevance of the Eemian for the study of the Palaeolithic occupation of Europe. Geologie en Mijnbouw/ Netherlands Journal of Geosciences 79: 283-291.

Stuart, A.J., 1976. The history of the mammal fauna during the Ipswichian/Last interglacial in England. Philosophical Transactions of the Royal Society of London B276: 221-250.

Stuart, A.J., 1995. Insularity and Quaternary vertebrate faunas in Britain and Ireland. In: Preece, R.C. (ed.) Island Britain: a Quaternary perspective. Geological Society Special Publication 96: 111-125.

Stuart, A.J. \& Lister, A.M., 2001. The mammalian faunas of Pakefield/Kessingland and Corton, Suffolk, UK: evidence for a new temperate episode in the British early Middle Pleistocene. Quaternary Science Reviews 20/16-17: 1677-1692.

Sutcliffe, A.J., 1964. The mammalian fauna. In: Ovey, C.D. (ed.): The Swanscombe Skull. Occasional Papers of the Royal Anthropological Institute 20: 85-111.
Sutcliffe, A.J., 1995a. Insularity of the British Isles 250 000-30000 years ago: the mammalian, including human, evidence. In: Preece, R.C. (ed.) Island Britain: a Quaternary perspective. Geological Society Special Publication 96: 127-140.

Sutcliffe, A.J., 1995b. The Aveley Elephant Site, Sandy Lane Pit (TQ 553807). In: Bridgland, D.R., Allen, P.\& Haggert, B.A. (eds) eds): The Quaternary of the lower reaches of the Thames. Field Guide. Quaternary Research Association (Durham): 189199.

Thieme, H., 1997. Lower Palaeolithic hunting spears from Germany. Nature 385: 807-810.

Thieme, H., 1999. Lower Palaeolithic Throwing Spears and Other Wooden Implements from Schöningen, Germany. In: Ulirich, $\mathrm{H}$. (ed.): Hominid Evolution, Lifestyles and Survival Strategies. Edition Archaea (Weimar): 383-395.

Thieme, H. \& Maier, R., 1995. Archäologische Ausgrabungen im Braunkohlentagebau Schöningen, Landkreis Helmstedt. Verlag Hahnsche Buchhandlung (Hannover): $200 \mathrm{pp}$.

Turner, C., 2000. The Eemian interglacial in the North European plain and adjacent areas. Geologie en Mijnbouw/Netherlands Journal of Geosciences 79: 217-231.

Turner, C. \& Kerney, M.P., 1971. A note on the age of the freshwater beds of the Clacton Channel. Quarterly Journal of the Geological Society of London 127: 87-93.

Tzedakis, P.C. \& Bennett, K.D., 1996. Interglacial vegetation succession: a view from southern Europe. Quaternary Science Reviews 14: 967-982.

Tzedakis, P.C., De Beaulieu, J.-L., Birks, H.J.B., Crowhurst, S., Follieri, M., Hooghiemstra, H., Magri, D., Reille, M., Sadori, L., Shackleton, N.J. \& Wijmstra, T.A., 2001. Establishing a terrestrial chronological framework as a basis for biostratigraphical comparisons. Quaternary Science Reviews 20/16-17: 1583-1592.

Urban, B., 1995. Palynological evidence of younger Middle Pleistocene interglacials (Holsteinian, Reinsdorf and Schöningen) in the Schöningen open cast lignite mine (eastern Lower Saxony, Germany). Mededelingen Rijks Geologische Dienst 52: 175185.

Urban, B., Thieme, H., Mania, D. \& Van Kolfschoten, T., 1995. Middle and Late Pleistocene and Holocene sequences in the open-cast pit of Schöningen / Niedersachsen. In: Schirmer, W. (ed.): Quaternary field trips in central Europe. Vol.3, field trips in Berlin and its environments. Verlag, Dr Dr. Friedrich Pfeil, Munich (XIV INQUA Congress): 1075-1077.

Vandenberghe, J., 1995. The Saalian Complex and the first traces of human activity in the Netherlands in a stratigraphic and ecologic context. Mededelingen Rijks Geologische Dienst 52: 187194.

Van der Made, J., 1999. Biometrical trends in the Tetraconodontinae, a subfamily of pigs. Transactions of the Royal Society of Edinburgh: Earth Sciences 89: 199-225.

Van der Made, J., 2000. A preliminary note on the rhinos from Bilzigsleben. Praehistoria Thuringica 4: 41-64.

Van Kolfschoten, T., 1993. Die Vertebraten des Interglazials von Schöningen 12B. Ethnographisch-Archäologische Zeitschrift 34: 623-628.

Van Kolfschoten, T., 2000. The Eemian mammal fauna of central Europe. Geologie en Mijnbouw/Netherlands Journal of Geosciences 79:269-281.

Van Kolfschoten, T. \& Turner, E., 1996. Early Middle Pleistocene faunas from Kärlich and Miesenheim I and their biostratigraphical implications. In: Turner, C. (ed.): The early Middle Pleistocene in Europe, INQUA Subcommission on European Quaternary Stratigraphy. Balkema (Rotterdam): 227-253.

Van Kolfschoten, T., Roebroeks, W. \& Vandenberghe, J., 1993. The Middle and Late Pleistocene sedimentary and climatic sequence 
at Maastricht-Belvedere: the Type Locality of the Belvedere Interglacial. Mededelingen Rijks Geologische Dienst 47: 81-91.

Von Koenigswald, W., 1986. Beziehungen des pleistozänen Wasserbüffels (Bubalus murrensis) aus Europa zu den asiatische Wasserbüffelen. Zeitschrift für Säugetierkunde 51:312-323.

Von Koenigswald, W., 1992. Various Aspects of Migrations in Terrestrial Mammals in Relation to Pleistocene Faunas of Central Europe. In: Von Koenigswald, W. \& von, Werdelin, L. (eEds.): Mammalian Migration and Dispersal Events in the European Quaternary. Courier Forschungsinstitut Senckenberg 153: 3947.

Von Koenigswald, W. \& Heinrich, W.-D., 1999. Mittelpleistozäne Säugetierfaunen aus Mitteleuropa - der Versuch einer biostratigraphischen Zuordnung. Darmstädter Beiträge zur Naturgeschichte 9: 53-112.

Ward, G.R., 1984. Interglacial fossils from Upminster, Essex. London Naturalist 3:24-26.

Warren, S.H., 1955. The Clacton (Essex) channel deposits. Quarterly Journal of the Geological Society of London 111:283-307.
West, R.G., 1969. Pollen analyses from interglacial deposits at Aveley and Grays, Essex. Proceedings of the Geologists' Association 80: 271-282.

White, M.J., 1998. Twisted ovate bifaces in the British Lower Palaeolithic. In: Ashton, N., Healy, F. \& Pettit, P. (eds) eds): Stone Age Archaeology. Essays in honour of John Wymer. Oxbow Monograph 102. Oxbow Books (Oxford): 98-104.

White, M.J. \& Schreve, D.C., 2000. Island Britain - Peninsular Britain: Palaeogeography, colonisation and the Earlier Palaeolithic settlement of the British Isles. Proceedings of the Prehistoric Society 66: 1-28.

Zagwijn, W.H., 1973. Pollenanalytic studies of Holsteinian and Saalian beds in the northern Netherlands. Mededelingen Rijks Geologische Dienst 24: 139-156.

Zagwijn, W.H., 1996. The Cromerian Complex Stage of the Netherlands and correlation with other areas in Europe. In: Turner, C. (ed.): The early Middle Pleistocene in Europe. Balkema (Rotterdam): $329 \mathrm{pp}$. 